\title{
Hindu Spiritualism: A Study of Upanishads and Yoga Sutras
}

\author{
Abid Mushtaq Wani \\ Shah-i-Hamadan Institute of Islamic Studies, University of Kashmir, Srinagar, India \\ Email address: \\ abidwani309@gmail.com \\ To cite this article: \\ Abid Mushtaq Wani. Hindu Spiritualism: A Study of Upanishads and Yoga Sutras. International Journal of Philosophy. \\ Vol. 9, No. 1, 2021, pp. 5-10. doi: 10.11648/j.ijp.20210901.12
}

Received: December 18, 2020; Accepted: January 13, 2021; Published: January 28, 2021

\begin{abstract}
Generally, Hinduism has two aspects within its paradigm, Ritualistic Hinduism and Spiritualistic Hinduism. First one is an institutionalized and organized religion with its holy books, rituals, priesthood, dogmas etc. The second one is a mystical outlook towards existence, a kind of spiritual humanism or freelance mysticism. This aspect of Hinduism is a continuation of the ancient wisdom traditions like Gnosticism and Neo-Platonism. The ritualistic aspect has its traditions in the form of Vedas, Shastras, and Puranas. Spiritualistic Hinduism can take many things from these traditions, but it's not strictly bound to their rules and regulations. The example of mystical Hinduism can be derived from the Upanishads, which are an amalgamation of philosophy and mysticism, and Yoga Sutras which are the general ethical and spiritual methods to reach to a state of equanimity and bliss. We can see Aurobindo Ghosh attesting Semitic prophets and including them in the broader spectrum of spirituality. We can observe Ramakrishna Paramhamsa worshipping in mosques and churches. We can know the essence of Bhakti movement with its inclusive and syncretistic philosophy and love. The ritualistic side is exclusivist and casteist and sometimes manifests itself in the form of dogmatism and exploitation. The common masses who follow the ritualistic side literally believe in thousands of gods and goddesses with their myriad stories and myths. But the Hindu philosophers like Professor Radhakrishnan know that all these mythological stories are just various metaphors for the One Absolute Reality known as Brahman in the Upanishads or Vedanta. I intend to highlight the spiritual, mystical and philosophical aspects of Hinduism or Vedanta.
\end{abstract}

Keywords: Spiritualism, Mysticism, Vedanta, Yoga, Brahman

\section{Introduction}

Spirituality is an important and inevitable experience of human consciousness. The human being is sometimes called homo religiosus, meaning, humans are a religious species and the sense of religiosity or spirituality is missing in all other species except homo sapiens. This is a fact as humans possess the most sophisticated and highest level of consciousness and all other beings except us lack this gift due to which they can't compete with humans in complex intelligence and emotions. It is only humans whose thought and behavior are shaped by some form of religious belief or experience. All ancient wisdom traditions and all the major religions give the highest importance to humanity as it is humans alone who are capable of religious thought. Spirituality is a basic ingredient of all the world religions but it can sometimes bypass the institutionalized or organized structure and become an individual phenomenon free of specific dogmas and boundaries of organized religion. Spirituality cannot be a study of empirical experimentation and it's not a subject matter of physical sciences, rather it's a subjective aspect of the human mind or soul. Though there are studies in the fields of psychology and neuroscience where it can be a subject of study in the form of behavioural studies and experimenting on the brain waves during intense spiritual states.

Joy, wonder, bewilderment, ecstasy and love are some of the key components of the spiritual path. A spiritual person often feels an alien in this world of transience and mortality and finds bliss in the remembrance of God or any chosen spiritual object. Moreover, the manifestations of this mystical tendency emerge in the form of tenderness, kindness, empathy and love towards one's fellow beings. People often need a purpose and meaning to their lives which only 
spirituality can provide them in its fullness. The rich religious life is most of the times saved from the existential dread which humans feel when they lack any definite purpose in life. A man feels that his death is not the end of the world and there's an Eternal Realm beyond every kind of physicality which is the abode of peace and tranquility. This encourages the human heart to go on in this world of uncertainty and insecurity, giving it the impetus to tolerate the worst kind of suffering and unease. Men of religion have shown utmost heroism in the midst of severe atrocities and afflictions, which is only possible if one has a higher ideal.

Spirituality is a vast subject which includes diverse perspectives. It includes within its fold a sense of relation and connection to something or someone larger than life and us, and it involves a search for purpose in life. In fact, it is a universal human experience, something that engulfs us all. People describe a spiritual experience in different ways, as Holy, Sacred or Transcendent or simply a deep sense of vitality and oneness with the whole Existence. Some find their spirituality in the membership and association of a temple, mosque, and church. Others may feel the need for constant prayers for being in connection with the Deity or a Higher Power. Some others may find spiritual upliftment in the beauty of nature and artistic endevour. The sense of spirituality may vary person to person or can be diverse within various religious groups.

In this paper, we are going to find out various sources of Hindu Spirituality or Mysticism describing various aspects of Hinduism. Indian Spiritual Philosophy is deeply found in Upanishads the philosophy of which is called Vedanta. The Upanishads are the booklets at the end of the four Vedas and their subject matter is highly Gnostic and Mystical. The spiritual descriptions in the Upanishads or the Vedantic School of Thought have no juristic or legal issues, rather they contain the profound statements about the Individual and Supreme Soul and how to attain Ultimate Bliss through contemplative and meditative practices so as to reach the Supreme Goal of Liberation, usually the merger with the Divine. There's also not propagated a single organized religion but the audience is humanity in general irrespective of creed or region.

\section{Religion and Spirituality}

Some scholars of religion and philosophers have clearly mad a distinction between religion and spirituality. While religion is a set of rules and regulations with its particular attributes of the Godhead, leadership, scriptures, precepts and an organized community for a group of scholars, Spirituality on the other hand is defined by some as a freeform and freelance activity of the soul which is not bound by any particular dogma or organization. Indeed, every religion contains within its fold the elements of spirituality but not all spiritual beliefs and practices can be kept under the paradigm of religion. The basic concepts of both religion and spirituality often overlap as we can see that the concept of God, Afterlife, Soul, etc are both common in religion as well as spirituality. Moreover, many strictly religious people claim that the true spirituality can only be found in a divinely revealed religion as only God is the Ultimate Source of Knowledge - This being the belief of most of the people belonging to Abrahamic faiths - Judaism, Christianity and Islam, we can add Zoroastrianism and Sikhism to this organized fold of spirituality as well as they all claim Divine Revelations from God Almighty and have their own authoritative figures in the form of Prophets and Gurus.

With Hinduism there is a twofold phenomenon, an aspect of this religion can be defined as an organized religion with its authority figures, dogmas, precepts, do's and don'ts' and Holy Scriptures. This side is highly ritualistic having a high reliance on caste-based duties, believing literally in the Puranic stories of Shiva, Vishnu and Devi, belief and reliance on astrology and horoscopes, diverse forms of deities and less emphasis on highly sophisticated mystical philosophies. Another side is rich in philosophy and mysticism relying mostly on Gnostic traditions derived from Upanishads, YogaSutras, Kashmiri Shaivism and other spiritualistic texts. Many Hindu sages and philosophers have propounded this mystical aspect of Hinduism especially after the NeoVedantic Movement made famous by Swami Vivekananda and other pioneers who also went to West to teach the Indian Spirituality to spiritually thirsty Westerners.

Hindu mystics like Ramakrishna Paramhamsa, Aurobindo Ghosh, Yogananda Paramhamsa etc have often attested the experiences of the prophets and leaders of other religions as there is a common saying in Hinduism; Ekam sat vipra bahudha vadanti "that which exists is One: sages call it by various names." The full verse of the Rigveda is this:

indram mitram varuNamagnimAhuratho sa divyo suparNo garutmAn |

ekam sadviprAh bahudhA vadanti agnim yamam mAtarishvAnamAhuh \|"'[1].

Let us take the example of Ramakrishna Paramahamsa, he was a devout worshipper and lover of the Motherly aspect of the Godhead, a Shakta, worshipper of Divine Mother Kali. But in his ecstatic love for the Divine, he adopted different paths throughout his journey of spirituality. He acted like a devout Muslim and prayed five times a day and experienced the Path of Islam. He also adopted Christianity during another phase and tasted the nectar of Christian Mysticism. Usually, this is not a behavior of the follower of an organized religion but these examples can be found in the perennial traditions of India. Giving expression to this unity in multiplicity, Aurobindo Ghosh states the experience of enlightenment in these profound words; "Mind and Life are disclosed in that illumination as at once figures and instruments of the Supreme Conscious Being by which It extends and houses Itself in material form and in that form unveils Itself to Its multiple centers of consciousness. Mind attains its self-fulfillment when it becomes a pure mirror of the Truth of Being which expresses itself in the symbols of the universe; Life, when it consciously lends its energies to the perfect self-figuration of the Divine in ever-new forms and activities of the universal existence"[1]. 
The aspect of Hinduism which we are describing here can be further explained by the Hindu acceptance of the experience of the sages of other religions. A philosophical and mystically inclined Hindu Scholar or a Layman can accept the experiences and visions of Jesus, Prophet Muhammad, Boddhi Dharma, Guru Nanak, Saint Teresa, Ibn Arabi, Saint John of the Cross, Meister Eckhart and others. Jesus' attachment with the God the Father, Muhammad's encounter with the Divine in the Night of Ascension, Saint Teresa's pangs of separation in the love of God, Nanak's mystical presence in the Abode of God - Every experience is validated by the spiritualistic, esoteric, perennial, gnostic, and mystical dimensions of Hinduism.

According to Professor Radhakrishnan the major tendency of the Indian mind is spirituality and it is has coloured its culture and thought. Spiritual experience is the foundation of Indian religious thought. Mysticism is the kernel of Indian Religion, not the codes, dogmas and rituals. While the Sacred Scriptures of the Hebrews and the Christians propound ethical codes and laws, those of Hindus are more spiritual and mystical [3].

Professor Radhakrishnan has made a sharp distinction between dogmatic religion and spirituality in one of his books. In dogmatic theology, the priest, jurist or a theologian accepts the Divine Revelation on the authority of other Holy Men making himself the expositor and interpreter of religion. Whatever his experience or investigation, they should always confirm the revealed doctrine. But the Philosophical Spirituality refuses to accept the authority of the scripture on face value. A Spiritualist confirms the ultimate nature of Reality by his own efforts in which he can also affirm the experiences of the sages who came before him. He rejects the a priori method of theology and adopts a scientific way of religion in which he relies on his own experiential realization. He tests and confirms the experiences and intuitions of the men of all creeds and religions without any preconceived notions or partiality. He keeps before him the whole spiritual history of humankind and avoids the disintegrating aspects of religious dogmatism [4].

\section{Upanishads}

Upanishads are one of the basic Hindu texts written in Sanskrit which propound the mystical philosophy of Hinduism such as Karma (Right Action), Brahman (The Ultimate Reality), Atman (The Soul), Moksha (Liberation) and various contemplative and meditative practices through which an individual human being can attain Gnosis or become one with the Divine, attaining final liberation from the cycle of births and deaths. The kernel of Upanishads or Vedanta is the Concept of Brahman or the Absolute Reality. The Eternal, Infinite, All Pervading Consciousness from which everything emanates and into which everything dissolves. Some call it God and some prefer to call it Absolute Being. It is the subtlest of the subtle and the fundamental stuff or reality of the Existence. An Impersonal Presence felt by the sages in deep meditative states or
Samadhis. Atman has two aspects - Universal and Individual, Paramatman and Atman. Many of the verses of the Upanishads often use Brahman and Atman as synonyms. This is because of the belief that Individual Soul is an inseparable part of the Universal Soul, The Brahman Itself. Due to the Veil of Maya or Cosmic Illusion, the individual soul forgets its true identity and sinks deep into the realm of matter and forgets its true destiny and abode. With highly sophisticated introspective and meditative practices the individual soul one day realizes that it is not only a drop in the ocean but the ocean itself. It then attains the gnosis or knowledge of Brahman and becomes one with the Absolute in Ultimate Bliss.

Upanishads are also called Vedanta, one reason is that they are the concluding portions of the Vedas - anta meaning end, hence Vedanta. Many other scholars say that because they are the Essence of the Vedas, that's why they are called the end of Vedas. Almost all philosophical systems of the Hindu thought are directly or indirectly related to Upanishads. They are the earliest Indian records of metaphysical speculative thought. They depict the yearning of every human heart to know and realize the nature of the Reality. Upanishads are not the product of a single author, rather, it's an encyclopedia of metaphysics stated by different saints and sages of Indian mysticism [5].

Adi-Shankara states that the Supreme Soul is the Ultimate Reality and Pure Intelligence for the harmonious sustenance of the Cosmos. For him, Brahman has no attributes and one cannot ascertain the attributes of the Absolute, one should remain silent regarding its attributes. Moreover, he also doesn't make any difference between the individual and Universal Soul and his understanding of the Upanishads or Vedanta leads him to the conclusion that there is no ontological difference between the Jivatama and Paramatma. Like space is the same in a house, water-vessel, jar and around, but in essence space is indivisible, similarly, Brahman is the only Lord in connection with various bodies. But paradoxically it is not to be understood that there is only one soul, there are indeed different individual souls until they realize their unity with the Brahman, they become one with It [6].

Some verses of the Upanishads should be stated an an example of their description of the indescribable Brahman. Munduka Upanishad states; "That which cannot be seen or seized, which has no origin, which has no properties, which has neither eyes nor ears, which has neither hands nor feet, which is eternal, diversely manifested, all-pervading, extremely subtle and imperishable, the wise regard as the source of all beings" [7]. "His form is not to be seen. No one beholds Him/It with eye. By controlling the mind, by the intellect and by incessant meditation $\mathrm{He}$ is revealed. Those who know this (Brahman) become immortal" [8].

Upanishad literally means 'sitting near' and it got its name from the tradition of Guru and Disciple. The seekers came to sages to gain insight into the spiritual matters and sat near them asking questions and receiving answers. The basic crux of these treatises is Self Realization when the self realizes its unity with the Self, it actually realizes itself as it is. The 
Upanishads have been recorded mainly from oral traditions before they were written down and there are hundreds of them. Later a section of the epic Mahabharata, The Bhagavad Gita was also included in the series of Upanishads because of its similar themes and philosophy. Great Indian Philosopher and former president of India, Professor Radhakrishnan describes Upanishads in these words; "The Upanishads are the concluding portions of the Vedas and the basis for the Vedanta philosophy, "a system in which human speculation seems to have reached its very acme," according to Max Muller. The Upanisads have dominated Indian philosophy, religion, and life for nearly three thousand years. Though remote in time from us, the Upanisads are not remote in thought. The ideal which haunted the thinkers of the Upanisads - the ideal of man's ultimate beatitude, the perfection of knowledge, the vision of the real in which the religious hunger of the mystic for direct vision and the philosopher's ceaseless quest for truth are both satisfied - is still our ideal [9].

\section{Yoga-Sutra}

The Yoga Sutra is the authoritative scripture on yoga, a collection of epigrams, describing the eight limbs of yoga. Sutra is a Sanskrit word meaning 'threads', technically the threads of wisdom and liberation. It is attributed to Maharishi Patanjali, a great Indian sage who compiled the experiences of Indian Rishis and Munis (Saints and Sages) on how to live an ideal life imbibing ethical precepts to purify one's self and to prepare oneself to attain the highest state of tranquility or Sat Chit Ananda - Truth, Consciousness and Bliss. Yoga literally means union, technically the union of the individual self with the Supreme Self. Yoga is mentioned in many Hindu scriptures but only Patanjali's Yoga-Sutra gives a systematic description of the practice of Yoga.

David Gordon White describes the contents of Yoga Sutra in these profound words; "There are four chapters containing 196 threads or aphorisms collectively on different aspects of the philosophy of Yoga. The first book is the Samadhi Pada where a Yogi is deeply immersed in a meditative state and his self is absorbed into the object being meditated upon. The second book is known as the Sadhana Pada containing various mental and physical exercises to further progress in the pursuit of spirituality. The third one is the Vibhuti Pada which states the various supernatural powers attained by a Yogi after years of deep meditative practices. And the last one is the Kaivalya Pada which describes the Ultimate State of the Liberation of the Soul.

The place where one would expect to find such references is the most straightforward and user-friendly portion of the Yoga Sutra, the second of its four chapters (padas), which is devoted to practice. Here, two types of practices are proposed. For the non-specialist, there is "practical yoga" (kriya yoga), which has three parts: asceticism, the study and recitation of sacred hymns and syllables, and dedication to Ishvara (Personal Deity). For the practitioner questing for liberation from suffering existence, Patanjali introduces the eight-part practice, which comprises the (1) inner and (2) outer restraints, (3) posture, (4) breath control, (5) retraction of the senses, (6) fixation, (7) meditation, and (8) pure contemplation. Comprising the final twenty-eight verses of chapter 2 and the three opening verses of chapter 3, Patanjali's presentation of the eight-part practice is a short respite from the highly theoretical focus of the greater bulk of his work" [10].

The opening statement in the Yoga Sutra defining Yoga is Chitta vritti nirodha. It is Patanjali's definition of yoga. It means that yoga is eliminating the fluctuations of the mind. Yoga is the calming of the mind, making it still until it reaches a state of complete bliss and tranquility, one experiences the reality as it actually is, not as our fickle minds show us. A Yogi experiences Life as One and rises above the duality of light and dark and good and bad. When the fickleness of the mind is totally eradicated, we become one with everything that is, one with the whole existence, the totality of the being - The Brahman. We experience a sense of oneness and unity with all that is and feel no separation between the potential and actual Divinity. Our inner Divinity actualizes and becomes the Divine Being. We have no separation from our inner divinity and the Divine. This is the essence and crux of yoga [11].

Hatha Yoga is a set of physical postures and exercises which make the body, the vessel of the Soul, flexible and healthy. A healthy body implies a healthy mind which is then prepared for intense meditative practices through various kinds of Dhyana or mystical mental practice. The Hatha Yoga then proceeds towards Raja Yoga which are the methodologies of mental exercise. In the words of famous Perennial Philosopher, Rene Guenon, “...the chief purpose of Hatha Yoga, at all stages, will be to lead up to Raja Yoga" [12].

\section{Kundalini Yoga}

An intense form of Yoga experienced and developed by various Indian sages is Kundalini Yoga which is the result of deep esoteric practices. It is believed that there are seven mystical energy centres or Chakras from the base of the spine to the head which is the crown chakra. Muladhara is the root chakra located at the base of the spine. Svadhisthana Chakra is located at the sacral area. Manipura Chakra is located on the navel area. Anahata is the heart chakra. Vishuddha is the throat chakra, Agya or Ajna chakra is the third eye located between the eyebrows on the forehead. Finally, the Sahasrara is on the top of the head also known as crown chakra. By various Yogic and Spiritual practices, Kundalini ascends upwards slowly from the lower to higher chakras finally reaching the crown chakra which is a moment of mystical enlightenment where the lower self merges the Higher Self and becomes one with the divine acquiring bliss and many supernatural powers as by-products. Kundalini literally means 'The Coiled One' and technically the energy which is coiled like a serpent at the base of the spine ready to emerge or open. A famous Indian sage, Swami Shivananda describes 
the phenomenon of Kundalini in these words; "Kundalini Yoga is that Yoga which treats of Kundalini Sakti, the six centres of spiritual energy (Shat Chakras), the arousing of the sleeping Kundalini Sakti and its union with Lord Siva in Sahasrara Chakra, at the crown of the head. This is an exact science. This is also known as Laya Yoga. The six centres are pierced (Chakra Bheda) by the passing of Kundalini Sakti to the top of the head. 'Kundala' means 'coiled'. Her form is like a coiled serpent. Hence the name Kundalini” [13].

A famous proponent of the Kundalini Yoga was Pandit Gopi Krishna, a Kashmiri Hindu, who according to his own account, experienced the rising of the Kundalini, and often stated the experiential stages of Kundalini in his lectures, interviews and books. As stated by various Indian sages and Tantric texts, there are dangers of practicing Kundalini Yoga without an expert Guide or Guru and without first purifying the body and the mind through various Yogic methods. According to Pandit Gopi Krishna, Kundalini experience is the kernel and epitome of every spiritual upliftment. This is the energy which is responsible for the spiritual experiences and mystical states of consciousness. He says that every religious experience can be traced back to Kundalini awakening and the meta-psychic experiences of the mystics can be only verified through the partial or complete awakening of Kundalini. This can bring the people of different faiths together when they realize that the revelations of their prophets and gurus have the same origin which they describe differently as per the cultural differences. It could also reduce the gap between empirical sciences and religion [14].

This Kundalini experience can be a blissful state described in all the mystical traditions. The Greek Ataraxia, Eastern enlightenment descriptions, Sufi Wajd and so on. Advaita Vedanta or experiencing the Divine intimately everywhere and within one's own self is also a part of this universal mystical human consciousness. "The mystic realizes the vivid presence of Brahman or Absolute in the minutest of the minute existences and in the self."[15]. Finally the crux of the Hindu Mysticism is that the Universe, Multiverse or Existence did not begin to exist. Everything eternally emanates from That and dissolves back into It. That or It being the Absolute Fundamental Reality which is the pure potentiality which actualizes everything. The Divine Seed which sprouts to create or manifest the tree of Existence. And to realize this is the epitome of human consciousness, realizing One Supreme Soul manifesting in different sentient and non-sentient entities. And our Ultimate Abode is the Ocean of which we are the drops. Therefore Atman has the same essence as the Brahman.

\section{Conclusion}

So far we have seen various aspects of Hindu Spirituality in light of the mystical philosophy of Upanishads and Yoga. It's evident from the above observations that the very essence of Hindu mysticism is a type of freelance mysticism which acknowledges the spiritual characteristics of the ancient perennial wisdom traditions, Gnosticism, Neo-Platonism, and all contemporary world religions. It is the esoteric essence of the outward manifestations of the Holy Scriptures and the revelations received by various spiritual personalities. A spiritually inclined person of any creed or no creed at all realizes the ephemeral nature of the material world and grasps the inner essence and the Ground of Existence through his intuitions received in mystical trances and ecstasies. It becomes almost impossible to put these experiences in words because of the imperfection of our languages. Hence Holy Scriptures and mystics talk in aphorisms and analogies to depict their respective inner subjective experiences. Through Dhyana or Meditation, a mystic goes on an inner journey which ends in the innermost destination of his being - The Atman or Soul where he realizes as the Non- Dual union between his self and the Self. This gnosis or direct knowledge of the higher dimensions of reality makes him serene, calm, tranquil and full of bliss. A common Hindu belief is that this world is a Leela of the Parameshwar, a Divine Play, with its own rules and regulations where the Supreme Soul expresses Itself in various confined bodies and objects. It's That Reality which dances in the Cosmic Drama and plays the game of 'hide and seek' with conscious beings where an individual has to find Him/Her/It to play and win.

The philosophy of Vedanta and Yoga have influenced many modern New-Age spiritual traditions such as the Theosophical Society. Many great philosophers have acknowledged the profundity of the Vedanta in expressing the reality of the macro and the microcosm. Arthur Schopenhauer had high regards for Upanishads and reconciled their philosophy with his own philosophy of 'Universal Impersonal Will'. Aldous Huxley was also among those Westerners who experienced the altered states of consciousness by his use of psychedelics like LSD and understood, to some extent, what mystical experiences feel like. He was also fond of the philosophy of Upanishads and considered them the expression of every mystical experience ever experienced by mystics. His famous book, 'The Perennial Philosophy' talks highly about the Indian mysticism, Bhagavad Gita and Yoga. In the modern era, many Westerners got highly impressed by various Indian Spiritual traditions and adopted their methodologies. From the Transcendental Yoga of the Maharishi Mahesh Yogi to the Kriya Yoga of Yogananda Paramahamsa, Westerners realized the importance of spiritual life when material goods and luxuries could not satisfy their thirst for the Eternal. The example of the Westerners coming towards the metaphysical ideologies given here is deliberate because they were the people of developed countries who had seen many luxuries of material goods but could not be still and calm because of the lack of something Permanent. This is the human predicament where after achieving enough material benefits they still find an emptiness in their hearts and minds which only the mysticism can satisfy, the realization and the practice of spiritualism only can quench the intense thirst of the human soul which saves us from existential crisis and mental disorientation. 


\section{References}

[1] Rig Veda 1.164.46.

[2] Shri Aurobindo, (2005), The Life Divine, Sri Aurobindo Ashram Publication Department, p-29.

[3] Sarvapelli Radhakrishnan, (1929), Indian Philosophy, V-1, Unwin Brothers, UK, p-42.

[4] Sarvapelli Radhakrishnan, (1976), An Idealistic Way of Life, George Allen and Unwin (India), New Delhi, p-68.

[5] Ibid, p-137-138.

[6] K. Satchidananda Murty, (2007), Evolution of Indian Philosophy, D. K. Print world, New Delhi, p-200-201.

[7] Munduka Upanishads, 1-1-6.

[8] Kathopanishad, 2-6-9.

[9] Sarvepalli Radhakrishnan and Charles A. Moore, (1957), A Sourcebook in Indian Philosophy, Princeton University Press, $\mathrm{p}-37$.

[10] David Gordon White, (2014), The Yoga Sutra of Patanjali-A Biography, Princeton University Press, UK, p-33.

[11] https://www.yogapedia.com/2/8458/meditation/silence/yogaschitta-vritti-nirodha.

[12] Rene Guenon, (2000), Introduction to the Study of Hindu Doctrines, Munshiram Manoharlal Publishers, New Delhi, p265.

[13] Swami Shivananda, (1999), Kundalini Yoga, Divine Life Society Publication, Uttar Pradesh, Preface, p-vi.

[14] Gopi Krishna, (1990), Kundalini, The Secret of Yoga, Kundalini Research Foundation, USA, Introduction, p-ii.

[15] Sircar, Mahendranath, (2018), Hindu Mysticism According to the Upanishads, Routledge, New York, p-175. 